\title{
SOCIO-ECOLOGY HOUSING : KAMPUNG VERTIKAL SEBAGAI RUMAH SUSUN DI PERMUKIMAN KUMUH MUARA BARU
}

\author{
Owen Sebastian ${ }^{1)}$, Sidhi Wiguna Teh ${ }^{2)}$ \\ 1)Program Studi S1 Arsitektur, Fakultas Teknik, Universitas Tarumanagara,owensebastian98@gmail.com \\ 2) Program Studi S1 Arsitektur, Fakultas Teknik, Universitas Tarumanagara, sidhi@ft.untar.ac.id
}

\begin{abstract}
Abstrak
Urbanisasi masyarakat menuju pusat kota untuk mencari lahan pekerjaan dan penghidupan yang lebih layak menjadi salah satu faktor awal memunculkan area kumuh di perkotaan. Masyarakat yang datang kurang dalam mempersiapkan keahlian / ilmu pengetahuan sehingga keadaan ekonomi mereka tidak mampu memiliki tempat tinggal yang ada di perkotaan. Tempat tinggal yang merupakan salah satu kebutuhan pokok, mendesak masyarak yang kurang mampu mendirikan tempat tinggal sederhana tanpa penyediaan fasilitas dan utilitas yang memadai, sehingga memunculkan permukiman kumuh. Daerah Muara Baru merupakan salah satu daerah kumuh yang terletak di Kelurahan Penjaringan, Jakarta Utara. Daerah kumuh yang tidak tertata dengan baik ini memberikan efek negatif bagi lingkungan dimana daerah kumuh itu berada. Kampung vertikal ini merupakan salah satu solusi untuk meningkatkan kualitas hidup manusia dengan menata permukiman kumuh. Desain kampung vertikal ini bertujuan untuk menjawab masalah ekologi yang ditimbulkan oleh permukiman kumuh terutama di daerah Muara Baru. Maka, dengan tujuan meningkatkan kualitas hidup warga dan mengembalikan kualitas lingkungan yang baik, melalui konsep keseharian dan prinsip ekologi, Kampung Vertikal ini hadir sebagai ruang pemulihan. Mengoptimalkan unsur alam, melibatkan aktivitas sehari-hari warga di permukiman kumuh, dan penerapan program ruang yang efisien dan bermanfaat untuk penghuni dan alam diharapkan dapat memulihkan kembali ekologi sosial dan lingkungan permukiman kumuh.
\end{abstract}

Kata kunci: kumuh; kampung vertikal; lokalitas; muara baru

\begin{abstract}
The urbanization of people towards the city center in search of employment and a better life was one of the initial factors that led to the emergence of slum areas in urban areas. Communities who come lack in preparing skills / knowledge so that their economic situation is not able to have a place to live in urban areas. Housing which is one of the urgent basic needs of people who are less able to build simple housing without the provision of adequate facilities and utilities, thus giving rise to slum settlements. The Muara Baru area is one of the slum areas located in Penjaringan Village, North Jakarta. Slum areas that are not well organized have a negative effect on the environment where the slums are located. This vertical village is one solution to improve the quality of human life by organizing slum settlements. This vertical village design aims to answer the ecological problems caused by slum settlements, especially in the Muara Baru area. So, with the aim of improving the quality of life of residents and restoring good environmental quality, through daily concepts and ecological principles, this Vertical Village is present as a recovery space. Optimizing natural elements, involving the daily activities of residents in slums, and implementing efficient and beneficial space programs for residents and nature are expected to restore the social ecology and environment of slums.
\end{abstract}

Keywords: localities; Muara Baru; slums; vertical villages 


\section{Pendahuluan}

"Housing is absolutely essential to human flourishing. Without stable shelter, it all falls apart." Matthew Desmond.

Kutipan di atas dapat menjadi gambar seberapa penting unsur perumahan dalam kualitas hidup manusia. Dalam perkembangan jaman juga dapat dipelajari evolusi perkembangan tempat tinggal yang disesuikan dengan kebutuhan. Keadaan lingkungan menjadi faktor penting yang perlu dipertimbangkan dalam membangun sebuah perumahan. Sampai saat ini, perumahan terus dibangun dimanapun aktivitas manusia berlangsung untuk memenuhi kebutuhan manusia akan tempat tinggal, terutama dalam manusia beraktivitas untuk mencari penghasilan.

\section{Latar Belakang}

Kondisi perkotaan di Indonesia yang umumnya berkembang pesat dan berfungsi sebagai pusat aktivitas serta menyediakan layanan primer dan sekunder, menjadi faktor yang menarik penduduk dari daerah mencari kehidupan yang lebih baik melalui lapangan pekerjaan yang lebih memadai. Kondisi tersebut mengakibatkan terjadinya pertambahan penduduk yang lebih pesat dibanding kemampuan pemerintah dalam menyediakan hunian serta layanan primer lainnya. Tumbuh-lah kawasan permukiman yang kurang layak huni, bahkan yang terjadi pada berbagai kota cenderung berkembang menjadi kumuh, dan tidak dengan standar lingkungan permukiman yang sehat. Permukiman tersebut seringkali bukan pada peruntukan perumahan dalam RUTR. (Andas Budy, Freddy. 2017.)

Jakarta sebagai ibu kota negara menjadi salah satu kota yang pertumbuhan penduduk selalu mengalami peningkatan dalam kurun waktu sepuluh tahun terakhir (2010-2020) dengan rata-rata 88 ribu jiwa setiap tahun. Tingginya pertumbuhan penduduk mengakibatkan jumlah permukiman kumuh yang meningkat. Berdasarkan data dari BPS DKI Jakarta, pada tahun 2013 terdapat 223 RW tergolong sebagai permukiman kumuh. Angka ini ikut meningkat dengan bertambahnya penduduk, hingga tahun 2017 terdapat 443 RW tergolong sebagai permukiman kumuh berdasarkan data dari BPS DKI Jakarta. Jakarta perlu memutar otak untuk mencari solusi dari permukiman kumuh. Sebab, Dalam penelitian Tilly Alcayna-Stevens (2015) dengan judul Slum socio-ecology: an exploratory characterisation of vulnerability to climate-change related disasters in the urban context, telah memaparkan bagaimana dampak hubungan manusia khusus nya penduduk yang kumuh dengan lingkungan tempat mereka tinggal dengan menggunakan istilah slum-sosio ecology dalam pemaparannya.

Permukiman kumuh termasuk di Jakarta biasanya terletak di lokasi yang dianggap sebagai lahan terlantar yang tidak diinginkan atau tidak layak dihuni. Lahan basah, tepi sungai, atau lereng curam menjadi pilihan karena dekat dengan peluang ekonomi oleh kaum miskin. Namun, munculnya aktivitas manusia yang mempengaruhi fungsi alami lingkungan membuat fenomena alam lebih tidak dapat diprediksi. Lahan basah yang kondisi alaminya membantu penyerapan dan pelepasan air permukaan sebagai spons alami mulai tertutup dan hasilnya adalah gangguan pada sistem pengaturan air alami. Tanah yang mungkin dianggap "marjinal” pada kenyataannya memiliki fungsi ekologis kritis menajdi hilang melalui pemukiman yang tidak direncanakan dan sembarangan.

Munculnya permukiman yang tidak direncanakan membuat penduduk sangat bergantung pada sumber daya lingkungan untuk kelangsungan hidup. Misalnya, kurangnya akses sumber air yang lebih baik, sehingga bergantung pada sumur atau sungai secara langsung; bahan rumah tahan lama yang tidak terjangkau memaksa penebangan pohon, bahkan tidak tersedianya pembuangan limbah manusia menjadi penting. Limbah yang dihasilkan oleh aktivitas manusia (khususnya limbah manusia)dalam konteks kepadatan penduduk yang tinggi dapat menyebabkan degradasi lingkungan dan kondisi manusia. Ketika tidak ada sistem pengelolaan limbah, seperti kasus permukiman kumuh yang biasanya kekurangan infrastruktur sanitasi, sumber daya air yang kritis dapat dengan cepat tercemar. Limbah ini meningkatkan pengendapan sungai sehingga banjir lebih sering terjadi. Pada saatnya banjir dapat memperburuk pencemaran sungai karena toilet yang ada menjadi tersumbat, mengharuskan orang 
untuk buang air langsung di sungai, menciptakan spiral ke bawah yang terus memburuknya kondisi manusia dan lingkungan, meningkatkan risiko penyakit yang dapat menular, terutama penyakit yang ditularkan melalui air.

Dari fenomena yang ada mengenai dampak dari permukiman kumuh, menciptakan siklus degradasi kualitas pada manusia dan lingkunkungan. Oleh karena itu, sangat diperlukan penataan ulang dan desain hunian terencana yang memperhatikan lingkungan demi kesejahteraan penghuni. Namun, desain harus tetap menjaga karakteristik kehidupan kampung kota yang penuh keberagaman dan pertumbuhan yang organik. Menjadi sebuah isu tersendiri, bagaimana merencanakan desain arsitektural yang memadukan keseragaman (pertumbuhan terencana) dan keberagaman (pertumbuhan organik) dalam permukiman kampung kota.

\section{Rumusan Permasalahan}

Penyebab utama yang disimpulkan oleh penulis setelah mengumpulkan data dan menganalisis keadaan yang terjadi pada masa kini, yaitu bersumber dari rendahnya pengetahuan/keahlian masyarakat daerah yang melakukan urbanisasi ke perkotaan. Sehingga mempengaruhi kemampuan ekonomi mereka untuk memiliki hunian sebagai salah satu kebutuhan dasar manusia. Oleh karena itu, masalah dari perancangan ini berfokus pada penyediaan tempat tinggal / unit hunian yang layak dan penyediaan fasilitas-utilitas yang memadai untuk meningkatkan kualitas lingkungan dan manusia.

\section{Tujuan dan Manfaat Proyek}

Proyek ini dirancang dengan harapan dapat membatu masyarakat miskin untuk memenuhi salah satu kebutuhan utama manusia, yaitu tempat tinggal yang dapat meningkatkan kualitas manusia melalui pemulihan kualitas lingkungan tempat tinggal dan penyediaan program aktivitas untuk membantu perekonomian masyarakat miskin. Hal ini direalisasikan dengan menciptakan desain hunian kampung kota yang memiliki siklus berkelanjutan antara manusia dan lingkungan alam yang dilengkapi dengan program pelatihan urban farming dan fasilitas-utilitas sesuai standar, dengan harapan dapat mendorong masyarakat miskin untuk berkembang menjadi individu yang lebih terampil sehingga dapat memenuhi kebutuhan dasar dan bertahan hidup dalam masyarakat di kemudian hari.

\section{KAJIAN LITERATUR}

\section{Beyond Ecology}

Pengertian ekologi menurut Kamus Besar Bahasa Indonesia (KBBI) adalah cabang ilmu biologi yang mempelajari interaksi antara makhluk hidup dengan makhluk hidup lain dan juga dengan lingkungan sekitarnya. Dr. Suyud Warno Utomo, M. (2018) mengungkapkan, komponen yang terlibat dalam interaksi ini dapat dibagi menjadi komponen biotik (hidup) dan abiotik (tak hidup). Sementara kata melampaui (beyond) sendiri menurut KBBI memiliki arti melalui/ melintasi/ melebihi batas/ ketentuan dan mengarah kepada suatu tindakan.

Berdasarkan paparan dari pengertian setiap suku kata beyond ecology atau melampai ekologi merupakan sebuah ajakan untuk memiliki pola pikir atau pandangan mengenai interaksi makhluk hidup / subjek dengan lingkungan sekitar tidak pada masa sekarang saja dan tidak terpaku pada makhluk hidup / subjek yang terlihat sedang berinteraksi pada saat tertentu. Hal ini dikarenakan kata melampaui ekologi sendiri tidak memiliki definisi yang pasti atau rigid. Definisi dari melampaui ekologi dapat berbeda-beda tergantung subjek tertentu. Oleh karena itu, subjek perlu dikerucutkan terlebih dahulu agar beyond ecology dapat tercapai. Menurut penulis, beyond ecology adalah menciptakan penghidupan yang lebih baik dengan menghadirkan sesuatu yang sulit atau belum memperolehnya guna meningkatkan kualitas hidup. 


\section{Perumahan}

Menurut UU No. 4 Tahun 1992 tentang Perumahan dan Permukiman, perumahan berada dan merupakan bagian dari permukiman, perumahan adalah kelompok rumah yang berfungsi sebagai lingkungan tempat tinggal atau lingkungan hunian yang dilengkapi dengan prasarana dan sarana lingkungan (pasal 1 ayat 2). Kebijakan dan Strategi Nasional Perumahan dan Permukiman Departemen Permukiman dan Prasarana Permukiman (2002) menyebutkan bahwa, secara fisik perumahan merupakan sebuah lingkungan yang terdiri dari kumpulan unit-unit rumah tinggal dimana dimungkinkan terjadinya interaksi sosial diantara penghuninya, serta dilengkapi prasarana sosial, ekonomi, budaya, dan pelayanan yang merupakan subsistem dari kota secara keseluruhan. Lingkungan ini biasanya mempunyai aturan-aturan, kebiasaan-kebiasaan serta sistem nilai yang berlaku bagi warganya.

\section{Kampung}

Menurut Kamus Besar Bahasa Indonesia (KBBI) definisi kampung adalah kelompok rumah yang merupakan bagian kota; desa; dusun;kesatuan administrasi terkecil yang menempati wilayah tertentu, terletak di bawah kecamatan; terkebelakang (belum modern); berkaitan dengan kebiasaan di kampung; kolot; dan halaman daerah atau desa tempat kelahiran.

Sedangkan menurut para ahli, kampung merupakan kawasan pemukiman kumuh dengan ketersediaan sarana umum buruk atau tidak ada sama sekali, kerap kawasan ini disebut slum (Budiharjo, 1992). Secara garis besar bahwa kampung adalah kawasan kumuh yang minim dengan sarana umum, dan menurut Budiharjo bahwa kampung sudah dipastikan tergolong slum atau wilayah kumuh.

Kampung merupakan lingkungan tradisional khas Indonesia, ditandai ciri kehidupan yang terjalin dalam ikatan kekeluargaan yang erat. Kampung kotor yang merupakan bentuk pemukiman yang unik, tidak dapat disamakan dengan "slum" atau juga disamakan dengan pemukiman penduduk berpenghasilan rendah (Turner, 1972).

Kampung merupakan suatu kesatuan lingkungan tempat tinggal yang dihuni oleh sekelompok masyarakat yang terdiri dari kesatuan keluarga-keluarga. Kumpulan sejumlah kampung disebut desa. Kampung adalah satu-satunya jenis permukiman yang bisa menampung golongan penduduk Indonesia yang tingkat perekonomian dan tingkat pendidikan paling rendah meskipun tidak tertutup bagi penduduk berpenghasilan dan berpendidikan tinggi (Khudori, 2002).

Berdasarkan beberapa pengertian dari kbbi dan para ahli, kampung dapat didefinisikan sebagai tempat tinggal atau kelompok rumah yang ditempati oleh kelompok masyarakat dengan tingkat ekonomi dan pendidikan rendah. Kawasan kampung pada umumnya tidak memiliki fasilitas dan sarana umum atau kurang memadai sesuai standarisasi. Namum kampung memiliki keunikan dalam hubungan antara individu yang terjalin secara kekeluargaan dan pertumbuhan kampung yang memiliki ketidakaturan.

\section{Kampung Kota}

Pengertian kampung kota sendiri menurut Noviantri, R. U. (2019: 8-11) adalah kawasan bagian dari kota, terdiri atas kelompok perumahan, jumlah penduduk yang tinggi, kurang sarana dan prasarana, tidak terdapat luasan tertentu, dapat lebih besar dari satu kelurahan serta mengandung arti perumahan yang dibangun secara tidak formal. Kampung di dalam kota memiliki karakteristik tersendiri, yaitu kehidupan sebuah desa masih terdapat di dalamnya, yang masih nampak pada sistem sosial dan budaya yang mengikat. 


\section{Kampung Vertikal}

Menurut Yu Sing (2011), kampung vertikal merupakan transformasi dari kampung horizontal tanpa menghilangkan karakter lokal, kekayaan bentuk, warna, material, volume, garis langit (skyline, potensi ekonomi, kreativitas warga, dan lain sebagainya. Arsitektur kampung vertikal itu sendiri dipengaruhi oleh kearifan lokal dan kreativitas warganya. Merencanakan kampung menjadi kampung vertikal merupakan solusi untuk pertambahan penduduk di masa yang akan datang. Dengan adanya kampung vertikal diharapkan kapasitas ruang terbuka hijau lebih banyak, agar hubungan alam dan lingkungan dapat lebih bersahabat. Kampung vertikal dirancang dengan kapasitas minimal dua kali lipat jumlah rumah eksisting. Ukuran hunian kampung vertikal juga beragam, karena memang tingkat ekonomi dan kebutuhan masyarakat tidak seragam.

\section{Rumah Susun}

Berdasarkan undang-undang Republik Indonesia No.20 Tahun 2011 tentang rumah susun, rumah susun adalah bangunan gedung bertingkat yang dibangun dalam suatu lingkungan yang terbagi dalam bagian-bagian yang distrukturkan secara fungsional, baik dalam arah horizontal maupun vertikal dan merupakan satuan-satuan yang masing-masing dapat dimiliki dan digunakan secara terpisah, terutama untuk tempat hunian yang dilengkapi dengan bagian bersama, benda bersama, dan tanah bersama. Selanjutnya, rumah susun terbagi menjadi beberapa golongan, yaitu:

- Rumah susun umum adalah rumah susun yang diselenggarakan untuk memenuhi kebutuhan rumah bagi masyarakat berpenghasilan rendah.

- Rumah susun khusus adalah rumah susun yang diselenggarakan untuk memenuhi kebutuhan khusus.

- Rumah susun negara adalah rumah susun yang dimiliki negara dan berfungsi sebagai tempat tinggal atau hunian, sarana pembinaan keluarga, serta penunjang pelaksanaan tugas pejabat dan/atau pegawai negeri.

- Rumah susun komersial adalah rumah susun yang diselenggarakan untuk mendapatkan keuntungan

\section{Permukiman Kumuh}

Permukiman kumuh atau slum merupakan kondisi permukiman dengan kualitas buruk dan tidak sehat, tempat perlindungan bagi kegiatan marjinal serta sumber penyakit epidemik yang akhirnya akan menular ke wilayah perkotaan (UN Habitat, 2010). Diana Puspitasari dari Dinas Tata Ruang dan Permukiman (Distarkim) Kota Depok mengatakan, definisi permukiman kumuh berdasarkan karakteristiknya adalah suatu lingkungan permukiman yang telah mengalami penurunan kualitas. Dengan kata lain memburuk baik secara fisik, sosial ekonomi, maupun sosial budaya. Dan tidak memungkinkan dicapainya kehidupan yang layak bahkan cenderung membahayakan bagi penghuninya. Menurut Diana, ciri permukiman kumuh merupakan permukiman dengan tingkat hunian dan kepadatan bangunan yang sangat tinggi, bangunan tidak teratur, kualitas rumah yang sangat rendah. Selain itu tidak memadainya prasarana dan sarana dasar seperti air minum, jalan, air limbah dan sampah. Kawasan kumuh adalah kawasan dimana rumah dan kondisi hunian masyarakat di kawasan tersebut sangat buruk. Rumah maupun sarana dan prasarana yang ada tidak sesuai dengan standar yang berlaku, baik standar kebutuhan, kepadatan bangunan, persyaratan rumah sehat, kebutuhan sarana air bersih, sanitasi maupun persyaratan kelengkapan prasarana jalan, ruang terbuka, serta kelengkapan fasilitas sosial lainnya. 


\section{Kemiskinan}

Menurut Nugroho dan Dahuri (2012), kemiskinan merupakan suatu kondisi absolut atau relatif di suatu wilayah di mana seseorang atau kelompok masyarakat tidak mampu mencukupi kebutuhan dasarnya sesuai tata nilai atau norma yang berlaku. Jika dipandang dari aspek ekonomi, kemiskinan menunjuk pada gap antara lemahnya purchasing power dan keinginan dalam memenuhi kebutuhan dasar. Secara konsep, kemiskinan dapat dibedakan menjadi kemiskinan absolut dan kemiskinan relatif. Kemiskinan absolut memandang kemiskinan dalam suatu ukuran yang besifat mutlak yang bermuara atau berwujud sebagai garis, titik, atau batas kemiskinan. Sementara kemiskinan relatif, memandang kemiskinan dalam suatu ukuran yang dipengaruhi ukuran-ukuran lain yang berhubungan dengan proporsi atau distribusi (Nugroho dan Dahuri, 2012: 184). Seseorang atau keluarga dapat dikatakan miskin atau hidup dalam kemiskinan jika pendapatan mereka atau akses mereka terhadap barang dan jasa relatif rendah dibandingkan kebanyakan orang dalam perekonomian. Selain itu, kemiskinan dapat dilihat sebagai tingkat absolut dari pendapatan atau standar hidup (Van den Berg, 2005: 509).

\section{Urban Farming}

Pertanian perkotaan (urban farming) sudah mulai muncul pada zaman Mesir Kuno dimana sampah yang dihasilkan oleh masyarakat pada waktu itu dipergunakan sebagai input pertanian. Menurut Food and Agriculture Organization (FAO) dalam (J. Smit, 1996), pertanian perkotaan adalah sebuah industri yang memproduksi, memproses, dan memasarkan produk dan bahan bakar nabati, terutama dalam menanggapi permintaan harian konsumen di dalam perkotaan, yang menerapkan metode produksi intensif, memanfaatkan dan mendaur ulang sumber daya dan limbah perkotaan untuk menghasilkan beragam tanaman dan hewan ternak. Definisi lain tentang urban farming menurut RUAF ialah pertanian dan peternakan yang terdapat di dalam dan di sekitar kota. Urban farming memiliki beberapa macam dalam penerapannya yakni: tipe produktif, tipe estetik, tipe ekologis, dan tipe industri. Urban farming berfungsi sebagai salah satu solusi dalam mengatasi permasalahan perkotaan dimana lahan pertanian semakin berkurang di daerah kota.

\section{METODE}

Perancangan dihasilkan dengan penerapan metode perancangan lokalitas dengan pendekatan aktivitas keseharian warga. Data-data yang dikumpulkan meliputi, keadaan, aktivitas, dan fenomena eksisting yang berlangsung pada masa sekarang yang nantinya digunakan untuk dianalisis dan mengidentifikasi permasalahan yang berupa ketidak mampuan masyarakat miskin untuk memenuhi kebutuhan tempat tinggal, serta keputusan untuk merancang kampung vertikal sebagai usulan proyek hingga penerapan program urban farming tipe produktif yang merupakan pertanian perkotaan sebagai pemenuhan kebutuhan pangan untuk personal dan tipe estetik dengan penanaman tanaman pangan ataupun hias sebagai fokus wadah rekreasi atau hiburan lokal warga yang asri untuk mengatasi permasalahan. Ide perancangan kemudian diintegrasikan dengan conth kampung vertikal terbangun lainnya kemudian diimplementasi dan dikembangkan dengan mempertimbangkan batasan-batasan lokasi yang ditentukan.

\section{DISKUSI DAN HASIL}

\section{Pemilihan Tapak}

Pemilihan lokasi / tapak yang sesuai untuk proyek berdasarkan kriteria tapak yang diperlukan, maka pemilihan lokasi kawasan antara lain :

a. Jumlah Penduduk Miskin di DKI Jakarta

Berdasarkan BPS Provinsi DKI Jakarta yang dapat dilihat pada tabel 1 mendata jumlah dan persentase penduduk miskin menurut kabupaten/kota di DKI Jakarta tahun 2017 dan 2018 mendapatkan Jakarta Utara memiliki jumlah penduduk miskin terbanyak. 
Tabel 1. Tabel Jumlah Penduduk Miskin Menurut Kabupaten/Kota di Provinsi DKI Jakarta, 2017 dan 2018

\begin{tabular}{lrrrr}
\hline & \multicolumn{5}{c}{$\begin{array}{c}\text { Jumlah dan Persentase Penduduk Miskin Menurut Kabupaten/Kota di Provinsi } \\
\text { KKI Jakarta, 2017 dan 2018 }\end{array}$} \\
\cline { 2 - 5 } Kab./Kota & \multicolumn{5}{c}{ Jumlah Penduduk Miskin (ribu) } & \multicolumn{2}{c}{ Persentasi Penduduk } \\
\cline { 2 - 5 } & 2017 & 2018 & 2017 & 2018 \\
\hline Kep. Seribu & 3 & 63 & 3 & 3 \\
\hline Jakarta Selatan & 70 & 91 & 4 & 3 \\
\hline Jakarta Timur & 96 & 33 & 3 & 4 \\
\hline Jakarta Pusat & 35 & 86 & 6 & 3 \\
\hline Jakarta Barat & 87 & 96 & & 5 \\
\hline Jakarta Utara & 99 & & 3 & 3 \\
\hline Suyyyy
\end{tabular}

Sumber : BPS Provinsi DKI Jakarta, 2019

b. Keberadaan Kawasan Kumuh

Kemiskinan dan kampung yang cenderung memunculkan kawasan / permukiman kumuh, maka perlu mempertimbangkan tingkat / jumlah permukiman kumuh di DKI Jakarta.

Tabel 2. Data 10 Kelurahan dengan RW Kumuh terbanyak di Provinsi DKI Jakarta, 2017

\begin{tabular}{|c|c|c|c|}
\hline No. & Kelurahan & Jumlah RW Kumuh & Peringkat \\
\hline 1 & Penjaringan & 12 & 1 \\
\hline 2 & Kampung Rawa & 8 & 2 \\
\hline 3 & Tanah Tinggi & 8 & 3 \\
\hline 4 & Mangga Dua Selatan & 8 & 4 \\
\hline 5 & Wijaya Kusuma & 8 & 5 \\
\hline 6 & Rawa Badak Utara & 8 & 6 \\
\hline 7 & Kali Baru & 8 & 7 \\
\hline 8 & Manggarai & 7 & 8 \\
\hline 9 & Keagungan & 7 & 9 \\
\hline 10 & Cipete Utara & 6 & 10 \\
\hline
\end{tabular}

Sumber : BPS Provinsi DKI Jakarta, 2018

Tabel 2 merupakan data 10 kelurahan dengan jumlah RW yang masuk dalam kategori kumuh terbanyak di DKI Jakarta. Berdasarkan data di atas didapati kawasan kumuh terbanyak berdasarkan kelurahan berada di Kelurahan Penjaringan, Jakarta Utara.

c. Masuk dalam data kampung kumuh yang akan ditata pemprov DKI Jakarta

Berdasarkan kriteria dan hasil pengamatan data yang diperoleh, maka Kawasan KelurahanPenjaringan, Kecamatan Penjaringan, Jakarta Utara menjadi kawasan terpilih. Kawasan ini merupakan kawasan industri dan pergudangan sehingga banyak warga yang bermata pencaharian sebagai buruh dan karyawan yang datang dari daerah. Banyaknya pendatang untuk mencari nafkah menyebabkan munculnya permukiman yang tidak terencana hingga menjadi permukiman kumuh. Pada kelurahan ini terdapat 3 kampung yang tergolong permukman kumuh, Kampung Gedong Pompa, Kampung Elektro, dan Kampung Marlina. 


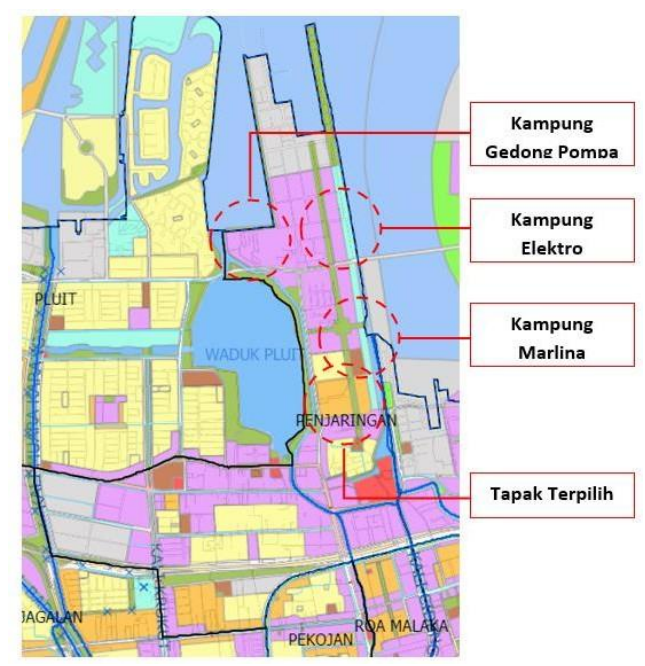

Gambar 1. Peta Tata Guna Lahan Kelurahan Penjaringan

Sumber : https://jakartasatu.jakarta.go.id/

Berdasarkan letak permukiman kumuh dan rencana tata guna lahan di Kelurahan Penjaringan sesuai dengan penjelasan gambar 1, lahan yang dapat digunakan sebagai area perumahan/permukiman diberi tanda dengan warna jingga dan kuning. Dimana tujuan proyek ini merancang suatu perumahan/permukiman, maka zonasi yang berwana jingga menjadi pilihan tapak pada proyek ini. Sehingga area permukiman kumuh yang terdekat dengan tapak relokasi adalah Kampung Marlina.

\section{Data Tapak}

Tapak terpilih berada di Jalan Muara Baru Raya yang merupakan jalan kolektor pada kawasan muara baru, menghubungkan antara Jalan Pluit Selatan Raya dan Pelabuhan Muara baru. Tapakini terpilih karena fungsi lahan yang sesuai dengan rencana tata guna lahan dan jangkauan darikampung eksisting (Kampung Marlina) yang tidak lebih dari radius $1 \mathrm{~km}$. Tapak terpilihi beradapada zonasi campuran (C1) dengan luasan 14.350 m2, KDB 50\%, KDH 30\%, KLB 2, KTB 55\% danKB 4.

\section{Program Kegiatan}

Analisis program kegiatan ini bertujuan untuk mengetahui kegiatan apa saja yang dilakukan warga kampung marlina pada bangunan perencanaan untuk memperoleh program apa saja yang diperlukan untuk mewadahi kegiatan para pengguna. Identifikasi kegiatan meliputi program aktivitas yang berlangsung pada proyek perencanaan, meliputi:

\section{a. Hunian}

Pada proyek kampung vertical ini, hunian menjadi program utama dengan persentase $70 \%$ dari total luas bangunan dan terdapat 4 tipe unit hunian yang tersedia. Pertama adalah hunian tipe 12 dengan kapasitas 1 orang yang berjumlah 65 unit, hunian tipe 18 dengan kapasitas 2 orang berjumlah 122 unit, hunian tipe 27 dengan kapasitas 3 orang berjumlah 40 unit, dan hunian tipe 36 dengan kapasitas 4-5 orang berjumlah 150 unit. Dasar penentuan tipe hunian ini didasari dari data jumlah anggota keluarga di kampung marlina dan analisis kebutuhan ruang gerak per orang yang telah dipaparkan secara detail pada gambar 2. 


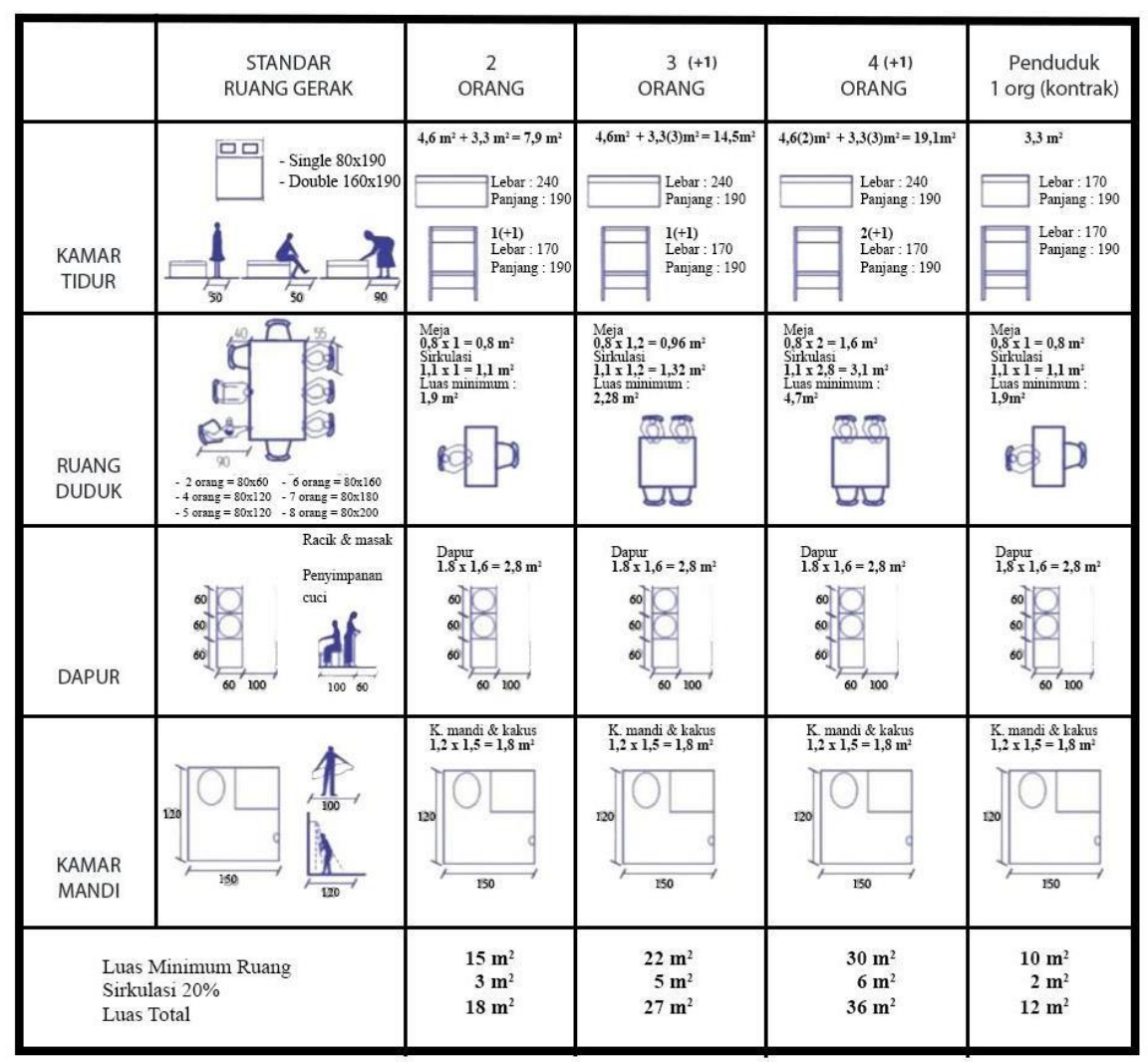

Gambar 2. Analisis Kebutuhan Ruang Gerak Orang Sumber : Analisa Penulis, 2021

Desain unit hunian dibuat dengan konsep modular. Modul berukuran $3 \mathrm{~m} \times 3 \mathrm{~m}$ yang nantinya dikomposisikan sesuai kebutuhan luas unit berdasarkan jumlah anggota dalam satu keluarga. Masing-masing unit akan terdisri dari 1-4 modul, dengan penerapan secara mendetail sebagai berikut :

1) Desain Unit Hunian Tipe 12

Dapat dilihat pada gambar 3, hunian tipe 12 terdiri dari 11/2 modul yang digunakan sebagai 1 ruang tidur, 1 kamar mandi, 1 ruang kerja/ruang makan, dan balkon.

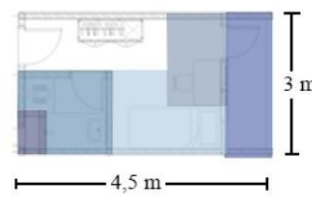

UNIT HUNIAN TIPE 12

Jumlah Modul : $11 / 2$

Ukuran Modul : $3 \mathrm{~m} \times 3 \mathrm{~m}$

Kapasitas : 1 orang

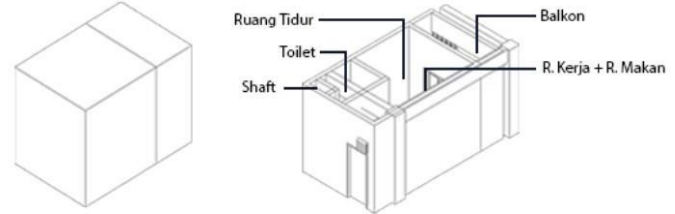

Gambar 3. Desain Unit Hunian Tipe 12

Sumber : Dokumentasi Penulis, 2021

2) Desain Unit Hunian Tipe 18

Dapat dilihat pada gambar 4, hunian tipe 18 terdiri dari 2 modul yang digunakan sebagai 1 ruang tidur, 1 kamar mandi, 1 dapur, 1 ruang kerja/ruang makan, dan balkon. 


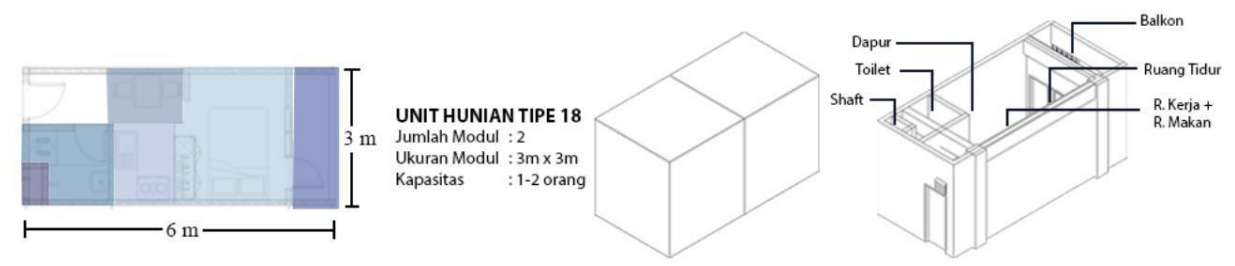

Gambar 4. Desain Unit Hunian Tipe 18

Sumber : Dokumentasi Penulis, 2021

3) Desain Unit Hunian Tipe 27

Dapat dilihat pada gambar 5, hunian tipe 27 terdiri dari 3 modul yang digunakan sebagai 2 kamar tidur, 1 kamar mandi, 1 dapur, 1 ruang kerja/ruang makan, dan balkon.
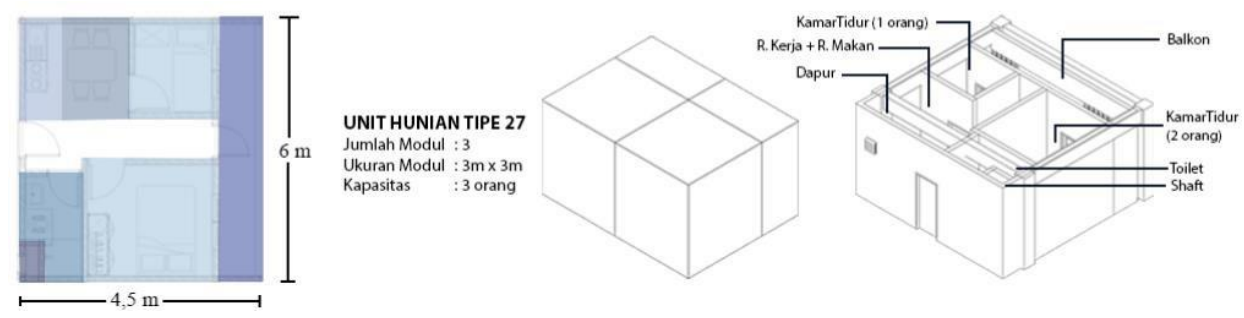

Gambar 5. Desain Unit Hunian Tipe 27

Sumber : Dokumentasi Penulis, 2021

4) Desain Unit Hunian Tipe 36

Dapat dilihat pada gambar 6 , hunian tipe 36 terdiri dari 4 modul yang digunakan sebagai 2 kamar tidur, 1 kamar mandi, 1 dapur, 1 ruang kerja/ruang makan, dan balkon.
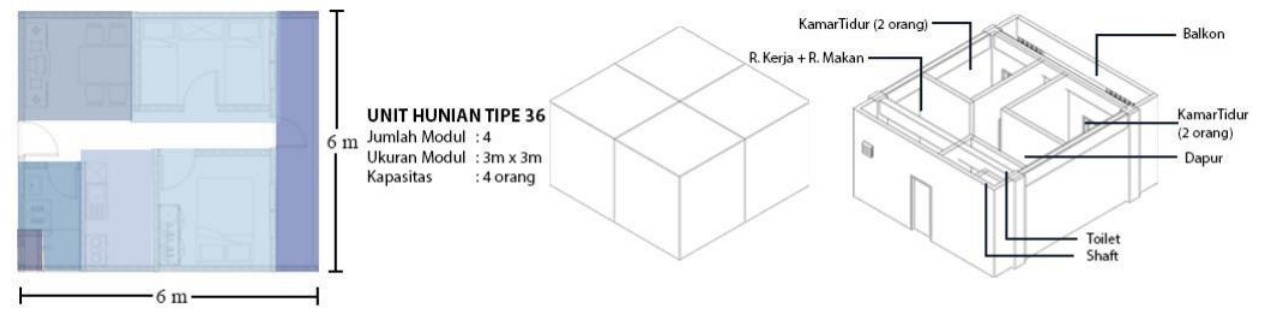

Gambar 6. Desain Unit Hunian Tipe 36

Sumber : Dokumentasi Penulis,2021

\section{b. Pelataran Usaha}

Area pelataran usaha sebesar $5 \%$ dari total luas bangunan dibuat dengan tujuan mewadahi pekerjaan warga setempat yang membuka usaha sebagai pedagang kaki lima (pkl) yang mulanya berdagang di sepanjang jalan muara baru raya. Zonasi pelataran usaha ini berada di posisi depan tapak, sehingga mempermudah akses pengunjung untuk berbelanja dan tidak mengganggu privasi hunian.

c. Mushollah

Mushollah disediakan untuk memenuhi kebutuhan warga kampung untuk beribadah dan mengikuti standar nasional Indonesia mengenai penyediaan fasilitas menurut jumlah jiwa pada suatu area tempat tinggal.

d. Paud

Paud sebesar 1,5\% dari luas bangunan disediakan untuk memenuhi kebutuhan warga dalam pendidikan untuk anak-anak usia 1-5 tahun, sehingga lokasi pencapaian harus dekat dan aman. Selain itu, penyedian paud juga mengikuti standar nasional Indonesia mengenai penyediaan fasilitas menurut jumlah jiwa pada suatu area tempat tinggal. 


\section{e. Area Komunal}

Titik-titik ruang komunal tersebar pada area unit hunian sekaligus membentuk cross ventilation pada masa bangunan dengan pembagian sebesar $7 \%$ dari total luas bangunan. Posisi ruang komunal yang tersebar ini bertujuan untuk memberi kesan ketidakaturan dalah hunian seperti halnya di area kampung. Penyediaan ruang komunal ini dipadukan dengan community garden yang bertujuan sebagai area pembelajaran awal untuk menuju urban farming.

f. Taman Dalam (inner courtyard)

Taman dalam sebesar $30 \%$ dari luas tapak dibuat dengan tujuan untuk melancarkan sirkulasi udara, memberi kesejukan di iklim tropis, dan menambahkan pemandangan bagi unit huian. Penyediaan tam aini juga untuk memenuhi ketentuan koefisien dasar hijau (kdh) pada tapak perencanaan.

\section{g. Urban Farming}

Urban farming dimasukan dalam proyek sebesar 15\% dari total luas bangunan, bertujuan untuk membantu dan meningkatkan perekonomian warga kampung dengan memanfaatkan hasil tanam untuk kebutuhan pangan sehari-hari warga serta dijual pada took pangan di area pelataran usaha.

Program kegiatan pada proyek perancangan terdiri dari tiga zona utama, yaitu zona hunian sebesar $70 \%$, zona urban farming sebesar $15 \%$, dan zona fasilitas pendukung sebesar $15 \%$. Zona hunian terletak pada lantai 1-4 dengan memiliki empat tipe unit hunian yang disesuaikan dari jumlah anggotadalam satu keluarga dan dilengkapi dengan beberapa titik ruang sosial yang ditempatkan secara menyebar pada setiap lantai. Zona urban farming terletak pada lantai atap dengan aktivitas berkebunyang menggunakan metode penanaman hidroponik dan konvensional. Zona fasilitas penunjang terletak pada lantai satu yang terdiri dari pelataran usaha, kios/warung, kelas urban farming, paud, apotek, posyandu, taman, lapangan olahraga, parker, dan utilitas.

\section{Konsep dan Bentuk Perancangan}

Proses perancangan dimulai dari tahap membentuk gubahan massa yang dihasilkan dari hasil analisis tapak dan kondisi sekitar tapak. Ilustrasi proses gubahan massa dapat terlihat pada gambar 7 . Tahaptahap proses gubahan massa seperti berikut:

a. Penentuan batas tapak perancangan sebagai acuan garis terluar dalam peletakan massa bangunan.

b. Massa bangunan dipotong secara diagonal dari 3 titik sudut yang merupakan akses sirkulasi keluar masuk tapak, hal ini bertujuan untuk memberikan kesan ketidak aturan kampung pada tapak yang persegi.

c. Pemisahan zonasi antara area komersil (pelataran usaha) diposisikan pada bagian depan tapak dan area hunian diposisikan pada bagian belakang. Pemisahan zoning ini akan memberikan privasi pada area hunian.

d. Massa bangunan pada area hunian disusun vertical keatas hingga 4 lantai, sesuai dengan ketentuan rencana detail tata ruang (RDTR) wilayah provinsi DKI Jakarta.

e. Menambahkan area void pada massa hunian untuk memaksimalkan pengudaraan dan pencahayaan alami.

f. Menambahkan struktur dan unit hunian dengan system modular untuk memkasimalkan luasan pada bangunan dan meminimalisir biaya konstruksi. 


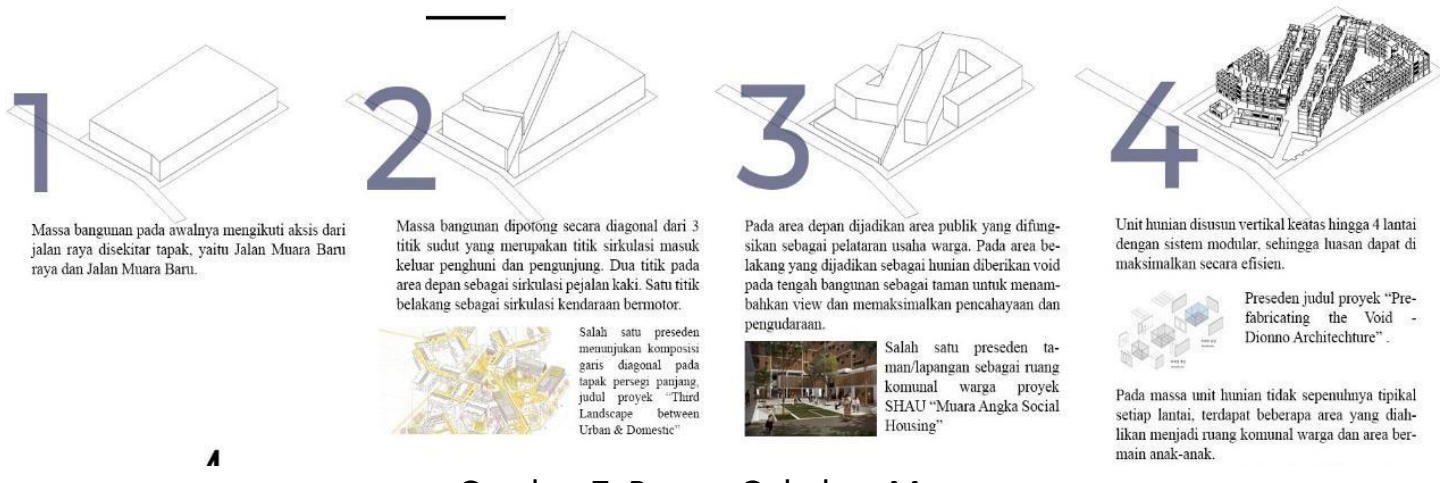

Gambar 7. Proses Gubahan Massa

Sumber : Dokumentasi Penulis, 2021

\section{Area Urban Farming}

Program urban farming seluas $3.000 \mathrm{~m}^{2}$ dimasukan kedalam proyek dengan tujuan, meningkatkan keadaan perekonomian warga kapung, menjadi wadah interaksi sosial antar warga, membantu pemulihan kualitas lingkungan terutama polusi udara, memaksimalkan ruang infrastruktur, dan menjadikan ruang terbuka hijau. Pada gambar 8 , dapat dipahami lebih detail mengenai sistem urban farming pada proyek ini yang menggunakan metode penanaman hidroponik dan konvensional, dengan macam sayuran berupa sawi hijau, sawi keriting, cabai, tomat, terong, dan pakchoi.

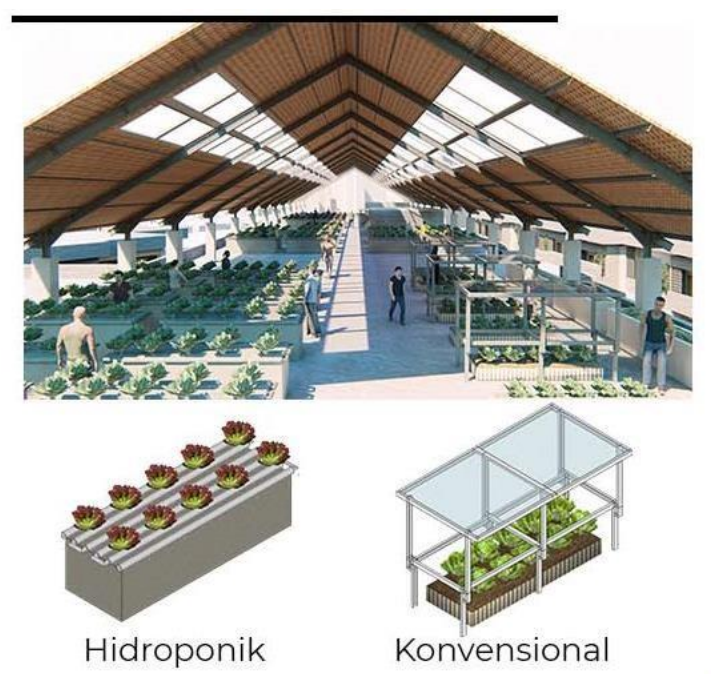

Ditempatkan pada lantai rooftop dengan sebagian atap menggunakan material kaca agar sinar matahari dapat masuk pada area tengah.

\section{Economic development 13 Business development}

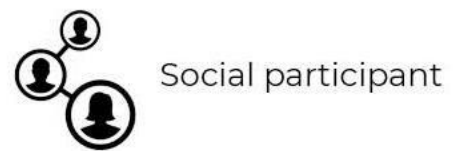

Enviromental polution
Atitude and Behavior

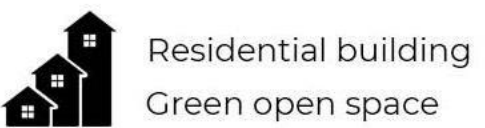

Macam Sayur (tanaman)

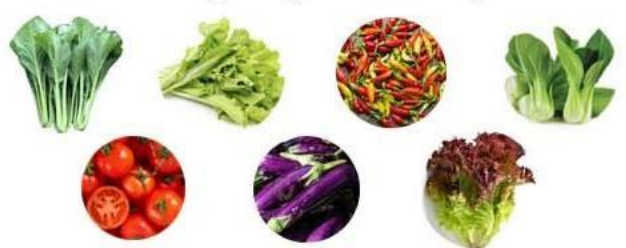

Gambar 8. Diagram Urban Farming pada proyek Sumber : Dokumentasi Penulis,2021 

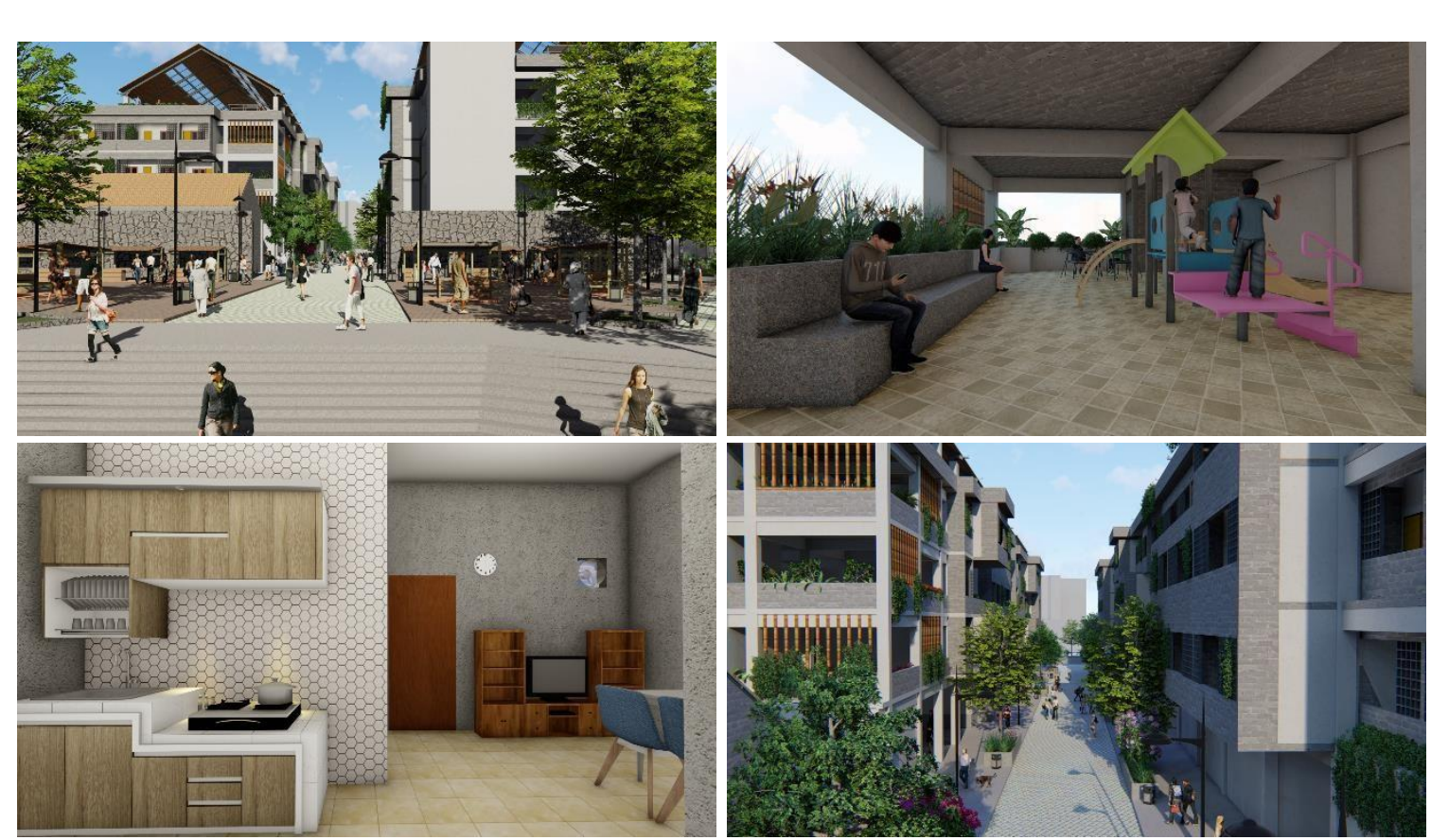

Gambar 9. Perspektif Eksterior (kiri atas), Area Bermain Anak pada Zona Hunian (kanan atas), Interior Unit Tipe 36 (kiri bawah), Area Selasar (kanan bawah)

Sumber : Dokumentasi Penulis,2021

\section{KESIMPULAN DAN SARAN}

\section{Kesimpulan}

Berdasarkan hasil pengumpulan data dan analisis, peningkatkan ketrampilan masyarakat miskin melalui pelatihan urban farming menjadi kelebihan pada proyek ini yang dapat membantu dan meningkatkan keadaan ekonomi masyarakat miskin sehingga dapat memenuhi kebutuhan tempat tinggal. Penggunaan sistem modular pada unit hunian dan material lokal juga membantu efisiensi biaya bangunan dengan desain yang sederhana dan efektif. Namun, mobilitas dan perubahan keadaan lingkungan yang begitu dinamis menjadikan perkembangan kualitas hidup setiap keluarga memiliki kecepatan yang berbeda. Pada proyek ini masih memiliki keurangan dalam fleksibelitas perubahan besaran unit apabila dibutuhkan pada satu keluarga tertentu. Diharapkan proyek ini dapat mendorong masyarakat atau pihak lain untuk dapat terus menghasilkan solusi dalam menangani masyarakat miskin dan permukiman kumuh dengan tidak meratakan kampung kota/permukiman kumuh yang ada.

\section{Saran}

Mendapatkan tempat tingal/hunian yang layak merupakan salah satu kebutuhan manusia yang sangat fundamental dalam kaitannya kualitas hidup seseorang. Masih banyak kawasan perkotaan dengan permukiman kumuh di berbagai lokasi, salah satunya di DKI Jakarta. Penulis mengharapkan dengan dibuatnya jurnal ini akan memicu proyek lain untuk membantu mengatasi permukiman kumuh di kawasan perkotaan. 


\section{REFERENSI}

Alcayna, T. \& Steven. (2015). Slum socio-ecology: an exploratory characterisation of vulnerability to climate-change related disasters in the urban context. Cambridge: Harvard University.

Andas B., Freddy. (2017). Penataan Kawasan Permukiman Kumuh Kelurahan Tamamaung Kota Makassar. Jurnal Arsitektur, Kota, dan Permukiman.

Arsyad, L. (1999). Pengantar Perencanaan dan Pembangunan Ekonomi Daerah. Edisi pertama. Yogyakarta: BPFE.

Berg, H. V. d. (2005). Economic Growth and Development. Singapura: McGrawHill.

Budiharjo, E. (1992). Sejumlah masalah perkampungan kota. Bandung: Alumni.

Departemen Permukiman dan Prasarana Wilayah. (2002). Kebijakan dan Strategi Nasional Perumahan dan Permukiman Departemen Permukiman dan Prasarana Permukiman. Jakarta.

Ekologi. (2012). Pada Kamus Besar Bahasa Indoneia Daring. Diakses pada 20 Mei 2021. <https://kbbi.web.id/ekologi>

J. Smit, A. R. (1996). Urban Agriculture: Food, Jobs, and Sustainable Cities. New York: UNDP.

Kampung. (2012). Pada Kamus Besar Bahasa Indoneia Daring. Diakses pada 20 Mei 2021. $<$ https://kbbi.web.id/kampung>

Khudori, D. (2002). Menuju Kampung Pemerdekaan membangun masyarakat sipil dari akar- akarnya : belajar dari Romo Mangun di pinggir Kali Code. Yogyakarta: Yayasan Pondok Rakyat

Melampaui. (2012). Pada Kamus Besar Bahasa Indoneia Daring. Diakses pada 20 Mei 2021. $<$ https://kbbi.web.id/lampau>

Nugroho, I. \& Dahuri, R. (2012). Pembangunan Wilayah : Perpektif Ekonomi, social, dan Lingkungan. Jakarta: LP3ES.

Perumahan \& Kawasan Permukiman. (2020). Pengertian dan Karakteristik Permukiman Kumuh, diakses pada 28 Maret 2021. <https://perkim.id/kawasan-kumuh/pengertian-dankarakteristik- permukiman-kumuh/>

Puspitasari, Diana. (2015). Permukiman Kumuh. Depok: Dinas Tata Ruang dan Permukiman (Distarkim) Kota Depok. [Makalah online]. <http://jakartapedia.bpadjakarta.net/index.php/Permukiman_Kumuh>

Republik Indonesia. (2011). Undang-undang Republik Indonesia Nomor 20 Tahun 2011 Tentang Rumah Susun. Jakarta: Pemerintah Pusat

RUAF. (2008). Why is urban agriculture important? Retrieved from ruaf: <https://www.ruaf.org> diakses pada 23 Mei 2021.

Suyud W. U., M. (2018). Pengertian, Ruang Lingkup Ekologi. Universitas Indonesia, diunduh pada 03 April 2021. <http://repository.ut.ac.id/4305/1/BIOL4215-M1.pdf>

Turner, J. F.C. (1972). Freedom to Build, Dweller Control of the Housing Process. New York: The Macmillan Company.

Yusing. (2011). Keberagaman Kampung Vertikal, diakses pada 28 Maret 2021. <http://rumahyusing.blogspot.com/2011/01/keberagaman-kampung-vertikal.html 
